\title{
Strengthen Accounting Integrity Research
}

\author{
Jieyu Qin \\ School of Economics and management, North China Electric Power University, Baoding, 071003, \\ China \\ email: 739864722@qq.com
}

Keyword: Accounting integrity, accounting staff

Abstract: Accounting integrity is the most important quality of accounting personnel. Strengthening the integrity construction of accountants is the requirement of the development of the times. In this regard, this paper starts from the reasons of the lack of accounting integrity, through a large number of investigations and studies, to solve the problems in them.

There are many problems in accounting practice. In response to these problems, 1,000 questionnaires are distributed to the staff of the staff, 848 valid questionnaires are collected, and the problems are quantified.

\section{Challenges faced by accounting integrity}

We distributed 1800 questionnaires and retrieved 1,500 questionnaires. The results of the survey are shown in Figure 1.

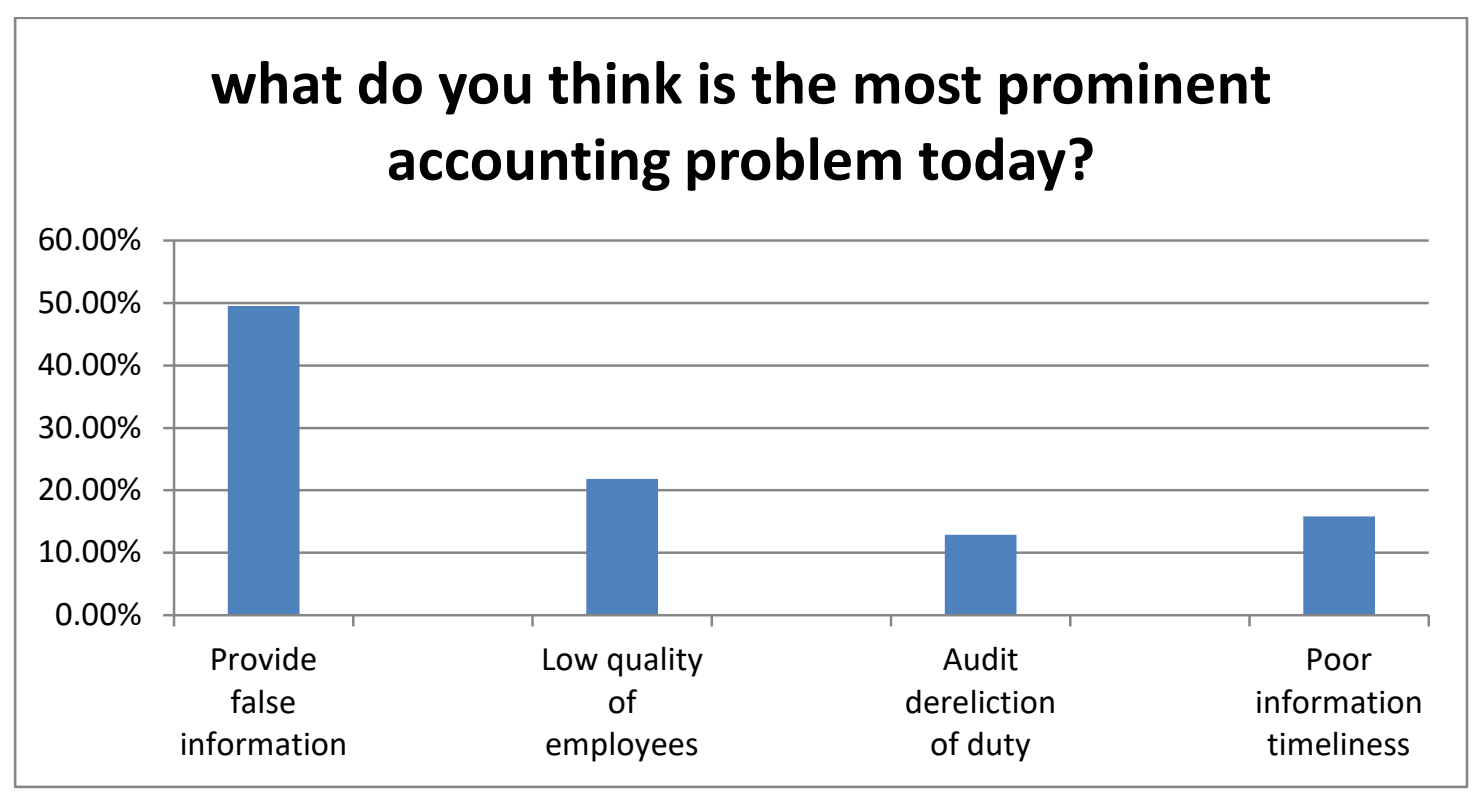

Figure 1: What do you think is the most prominent accounting problem? 
From the survey we got, $49.5 \%$ of people think that the accounting "fake accounts, provide virtual information" problem is the most serious. Secondly, the professional quality of accountants is not high, about one-fifth, and about $15 \%$ of people choose to provide accounting information is not timely. China's accounting legal system and professional ethics construction have achieved remarkable results. However, as there is a darkness in the sun, there are some other problems in the accounting professional ethics construction.

(1) The professional ethics is weak and the false accounts are common. In real life, quite a few accounting personnel with low moral quality are often unable to resist all kinds of temptations due to lack of objective and fair attitude and the spirit of excellence. They cannot adhere to the rules and often treat others with different accounting issues. Treating all parties to interests, even cheating together, making suggestions for illegal and disciplinary activities, directly participating in forgery, fabricating false accounting documents, accounting books, and accounting statements, so that accounting behavior deviates from the established accounting objectives, often at the expense of national interests. Benefits and even personal interests. The awareness of accounting personnel to abide by the law is becoming weaker, which is a serious distortion of the foundation of accounting professional ethics in reality. For example, (1) the duties and responsibilities of the book-keeping personnel and the economic and business matters and the examination and approval personnel, the handling personnel, and the finance ministers of the financial affairs are not clear. (2) For the significant foreign investment, asset disposal, fund scheduling and other important economic business. Disclosure in the process of mutual supervision and mutual control of decision-making and enforcement of matters (3) The scope, duration and organizational procedures of property inventories and the methods and procedures for regular internal audit of accounting information are not clear. There are also some accounting personnel who have individualism, money worship, hedonism expansion, lost the concept of the rule of law, deliberately forged, fabricated, concealed, and damaged accounting materials through the means of not collecting income, false reporting, and other means; using the position to embezzle and misappropriate public funds. Transfer the state and collective property to the hands of individuals and infringe on the interests of the state and the collective. It reflects that under the conditions of market economy, there are indeed some people in the accounting team who have lost their professional ethics and embarked on the path of the legal system.

(2) The business level is low. In reality, many accountants lack basic business quality, and accounting work frequently deals with errands. Their business knowledge is poor or their knowledge is aging, they have little knowledge of accounting standards and accounting systems, their professional and technical skills are poor, and their professional competence is obviously insufficient. The low quality of the business is also manifested in the lack of spirit of excellence in the work, the accounting is not in line with the norms, the books are confusing, the accounts are not consistent, and the number of statements is squeezed. In practice, it is not uncommon for accounting information to be distorted due to the unfamiliarity of accounting personnel. These have greatly reduced the quality of accounting work and violated the requirements of professional ethics.

(3) The audit information program is not in place. From the inspection situation, with the increase of supervision in recent years, the quality of corporate accounting information and the practice quality of accounting firms have generally improved, but the problem of accounting information distortion still exists, and some enterprises even have serious accounting fraud. At the same time, accounting firms also have serious problems. In the execution of routine audit procedures such as the letter-of-acquisition procedure and the substantive analysis procedure, the accounting firm has problems such as implementation not being implemented and implementation is not in place, and it is more common. 


\section{The quality that accounting personnel should have}

We have investigated the quality of accounting practitioners in the public today, as shown in Figure 2.

\section{what do you think are the most improtant qualities foe accountants?}

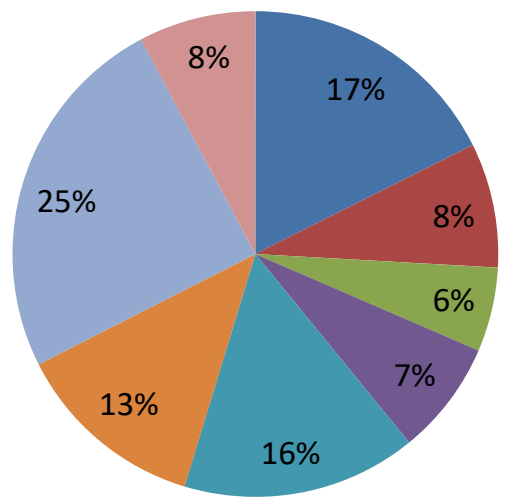

- Honesty

factory reset

Keep secret

Dedicated to love

a professional skill

objective and fair

Adhere to the guidelines

- Serving people

Figure 2: What do you think is the most important quality of accountants?

From the survey data, it is believed that accountants should have the best moral literacy, accounting for about one-third, followed by accountant's rich work experience and professional knowledge, accounting for about one-fifth. There are also some people who choose carefully and cautiously. When asked what do you think are the most important qualities of accountants? One in four chose the principle of adherence, followed by honesty and trustworthiness, accounting for one-sixth.

\section{Strengthen accounting integrity construction measures}

We analysed the results of the survey, as shown in Table 1.

From the survey data, the number of people who choose to "enhance accounting professional ethics education" is the most, followed by "establishing a sound regulatory and restraint mechanism, improving the reward and punishment mechanism", and some people have chosen "strengthening public opinion supervision". The professional ethics construction of accountants is a comprehensive project that requires the efforts of accountants, enterprises, society and the government. 
Table 1 Measures that should be taken for the status quo.

\begin{tabular}{|l|l|l|l|}
\hline Variable name & $\begin{array}{l}\text { variable } \\
\text { distribution }\end{array}$ & $\begin{array}{l}\text { observation } \\
\text { value }\end{array}$ & $\begin{array}{l}\text { standard } \\
\text { deviation }\end{array}$ \\
\hline $\begin{array}{l}\text { What do you think are effective ways to strengthen } \\
\text { the professional ethics of accountants? }\end{array}$ & $\begin{array}{l}0=\text { "Do not } \\
\text { choose" } \\
1=\text { "Selected" }\end{array}$ & (1526 & 0.385 \\
\hline $\begin{array}{l}\text { 1. Establish and improve the regulatory and restraint } \\
\text { mechanism and improve the reward and punishment } \\
\text { mechanism }\end{array}$ & $76.90 \%$ & 1526 & 0.346 \\
\hline 2. Improve the internal control system & $22.90 \%$ & 1526 & 0.385 \\
\hline $\begin{array}{l}\text { 3. Strengthen accounting professional ethics } \\
\text { education }\end{array}$ & $79.40 \%$ & 1526 & 0.32 \\
\hline $\begin{array}{l}\text { 4. Deepen the social credit system and purify the } \\
\text { industrial environment }\end{array}$ & $15.10 \%$ & 1526 & 0.376 \\
\hline 5. Strengthen public opinion supervision & $66.10 \%$ & 1526 & 0.352 \\
\hline $\begin{array}{l}\text { 6. Learn from the advanced methods of foreign } \\
\text { professional ethics }\end{array}$ & $34.20 \%$ & & \\
\hline
\end{tabular}

\section{The following measures can be taken.}

(1) Strengthen the construction of accounting professional ethics. The basic moral quality of accountants is the basis of the professional ethics of accountants. To strengthen the professional ethics of accountants, we must first strengthen the basic moral construction of accountants. At present, China's economic development is in an important transition period. Some accountants are affected by external bad ideas, the basic moral quality is corrupted, and professional ethics are lost for their own economic interests. On the one hand, the state and enterprises need to accelerate the building of spiritual civilization and correct the outlook and values of accountants. On the other hand, in the accounting qualification examination and the CPA exam, it is necessary to add relevant content of the moral quality examination, and strengthen the basic moral quality of the accounting personnel through the examination.

(2) Establish and improve the regulatory and restraint mechanism and improve the reward and punishment mechanism. Compared with similar developed countries, China's accounting management and reform is still in the initial stage of exploration. The legal policies in all aspects are still not mature, and the punishment for the lack of professional ethics of accountants is also very light, which reduces the illegality of accounting personnel to a certain extent. cost. In addition, most of China's enterprises have not been reasonable in assessing the performance of accounting personnel. They have not incorporated the professional ethics of accountants into the performance appraisal category. Some accountants have even been punished by enterprises for complying with professional ethics. In response to this situation, Chinese enterprises must clearly understand the importance of real accounting information to enterprises, and need to develop a scientific and reasonable performance appraisal system for enterprise accounting personnel, and use a comprehensive performance appraisal system to standardize and guide corporate accountants. The behavior ensures that all accountants consciously abide by professional ethics and ensure the authenticity of corporate accounting information. In addition, the relevant state organs should also strengthen the enforcement of laws, impose severe penalties on accounting personnel who violate relevant laws, increase the illegal costs of accounting personnel, and increase the illegal risks of 
accounting personnel.

(3) Strengthening public opinion supervision and improving the external supervision and performance appraisal of the performance appraisal of enterprise accountants is the guarantee for accountants to abide by professional ethics. At present, the audit work of Chinese enterprises is completed by accounting firms, and the accounting firms and the audited entities have direct economic interests. Therefore, only by strengthening the independent public opinion supervision of the accounting firm can ensure the fairness and reasonableness of the accounting firm and ensure the objective and fairness of the audit results.

\section{References}

[1] Reflections on Strengthening the Financial Ethics of Accounting Personnel in China [J]. Zhenyan Zhu. Financial Supervision. 2013(14)

[2] Analysis of the causes and countermeasures of the lack of accounting ethics [J]. Wei Zhang. Times Finance. 2012(18)

[3] Research on the construction of accounting professional ethics in the new era [J]. Ligang Zhang. Foreign investment in China. 2011(17)

[4] Analysis of the status quo and countermeasures of management accounting development in current enterprises [J]. Xuehui Yu, Xiaocheng Fan. Modern Business and Industry. 2010(07)程. 现代商贸工业. 2010(07)

[5]Update:International Education Standards Revision Project. IFAC. . 2012

[6]2014-2016 IAESB Strategy and Work Plan. IFAC. . 2013

[7]IAESB CAG Strategy Review. International Accounting Education Standard Board. . 2012

[8]The International Accounting Education Standards Board:Influencing Global Accounting Education. McPeak,D,K.V.Pincus, G.L.Sundem. Issues in Accounting Education . 2012

[9]IESBA Code of Ethics for Professional Accountants. .

[10]IEPS 1:Approaches to Developing and Maintaining Professional Values,Ethics and Attitudes. IFAC. . 2012

[11]IFAC Policy Position. IFAC. . 2012 